SUBSTANTIVE ISSUES IN INTERNATIONAL ECONOMIC LAW 



\title{
STILL GOING "GREY” AFTER ALL THESE YEARS? EXPORT-RESTRAINT AGREEMENTS AND THE WTO
}

\author{
Antonello Tancredi*
}

\section{INTRODUCTION}

As is made clear from the preamble of the WTO Agreement on Safeguards (hereinafter AS) - which includes the objective "[...] to re-establish multilateral control over safeguards and eliminate measures that escape such control [...]" - the ban on any kind of export-restraint agreements ${ }^{1}$ and the revitalization of the safeguard clause were the two axes along which the strategy of re-incorporation of the socalled "grey area" measures within the multilateral discipline of international trade were to take place.

The ban enshrined in Art. 11.1.b) was in itself necessary to realign the practice of trade protection measures adopted by WTO Member States to conform with the fundamental principles on which the GATT/WTO is based, principles that had been violated for decades by the proliferation of $V E R s$ (unilateral private or public voluntary export restraints), VRAs (intergovernmental bilateral voluntary restraint agreements) and $O M A s$ (multilateral orderly market arrangements). However, the proliferation of grey area measures - a category which in principle includes any restriction on exports administered unilaterally by the exporters and/or their government, but induced by the importers and/or their government - is historically due not only to the absence of a specific discipline under GATT 1947 but also to the existence of incentives and practical conveniences (starting with the possibility to avoid the high costs of activating the "official" safeguard clause provided for by Art. XIX GATT), ${ }^{2}$ that have rendered VERs a more attractive option for governments pressurized by domestic industries in search of commercial protection. In sum, as has long been recognized in GATT documents, ${ }^{3}$ the solution to the problem of grey area measures did not lie with simply outlawing such measures.

\footnotetext{
* University of Palermo.

1 An illustrative list of such measures is provided for in footnote 4 to Art. 11 of the Safeguards Agreement, and includes "export moderation, export-price or import-price monitoring systems, export or import surveillance, compulsory import cartels and discretionary export or import licensing schemes, any of which afford protection".

2 See P. Hilpold, 'Die Neuregelung der Schutzmaßnahmen im GATT/WTO-Recht und ihr Einfluß auf “Grauzonenmaßnahmen', 55 Zeitschrift für ausländisches öffentliches Recht und Völkerrecht 1995, p. $89 \mathrm{ff}$., at p. 124, with reference to the necessity to render formal safeguard measures an attractive alternative to grey area measures.

3 Negotiating Group on Safeguards, MTN.GNG/NG9/W/21, $3_{1}$ October 1998, p. 20.
} 
In 2000 - after the expiry of the residual 1-year period granted under Art. 11.2 AS to phase out or bring into conformity with the Agreement on Safeguards one specific measure 4 per importing Member (once the deadline to phase out or bring into conformity all other measures in existence on 1 January 1995, had already expired on $3_{1}$ December 1998) - the WTO Committee on Safeguards noted that all notified measures were definitively phased out by 1 January $2000 .{ }^{5}$

Independently of the official WTO sources - which, even in these years of financial turmoil and consequent fears of protectionist outbursts, were inclined to portray a fairly reassuring picture ${ }^{6}$ - rumours of a "revival" of grey area measures have spread in the legal scholarship. ${ }^{7}$

The purpose of this work, therefore, is to try to assess how the dual strategy that aimed to eliminate "grey area" measures has worked out in practice, also in the light of the protectionist pressures unleashed by the current economic crisis. For this purpose, after providing a brief overview of the historic proliferation of these measures (paragraph 2), we will proceed to ask whether the attempt to render ordinary safeguard measures a more attractive alternative to VRAs has worked in practice (paragraph 3 ), and then analyse some of the intrinsic and extrinsic weaknesses of the ban itself (paragraph 4). We will then go on to review some cases of export-restraint agreements arguably falling within the exceptions to the ban enshrined in Art. 11.1.c) AS (paragraphs 5, 6, and 7), reaching the conclusion that

4 As is well-known, the only measure maintained in effect beyond ${ }_{31}$ December 1998, and until 31 December 1999, has been the "Elements of Consensus" between the EC and Japan, as reflected in the annex to the Agreement on Safeguards (see footnote 5 with reference to Art. 11). This was a bilateral, informal arrangement concluded in July 1991 that placed quotas on Japanese motor vehicle exports to the EC as a whole and to five specific EC Member States.

5 Committee on Safeguards, Minutes of the Meeting Held on 9 November $2000, \mathrm{G} / \mathrm{SG} / \mathrm{M} / 16$, 18 January 2001, para. 103; Committee on Safeguards, Report (2000), G/L/409, 23 November 2000, sec. IV.

6 At the end of 2009, it was calculated that the overall share of trade affected by new traderestricting or distorting measures that had been introduced since October 2008 remained small, approximately $1 \%$ of world merchandise trade (see Overview of the Developments in the International Trading Environment, Annual Report by the Director General, WTO Doc. WT/TPR/OV/12, 18 November 2009, pp. A3-A4). In the period between mid-October 2010 and mid-October 2011, new restrictive measures covered around $0.9 \%$ of world imports, less than recorded in the previous year (see Overview of the Developments in the International Trading Environment, Annual Report by the Director-General, WT/TPR/OV/14, 21 November 2011, p. 3). Along the same lines, in the legal scholarship, see B. Ruddy, The Critical Success of the WTO: Trade Policies of the Current Economic Crisis, 13 Journal of International Economic Law 2010, pp. $475 \mathrm{ff}$., according to whom the WTO "has passed the 'stress test' of this current economic crisis", in the sense that despite strong protectionist pressures, WTO Members have not made recourse to broad protectionist policies such as those of the 1930s (p. 489).

7 Y.-S. Lee, 'Revival of Grey-Area Measures? The US-Canada Softwood Lumber Agreement: Conflict with the WTO Agreement on Safeguards', 36 Journal of World Trade 2002, p. 155. See also M. Beise, Th. Oppermann, G. Sander, Grauzonen im Welthandel. Protektionismus unter dem alten GATT als Herausforderung an die neue WTO (Baden-Baden, 1998), p. 138, who reported that in 1997 the European Community and Norway concluded the Lachs Compromise, according to which Norway pledged to reduce, as from 1 July 1997 and for five years, its exports of salmon in the EC countries. The objective was to the provide protection to the fisheries industries in Scotland and Ireland. 
some of these agreements are WTO-inconsistent. Some brief remarks of a more general character will conclude this work (paragraph 8).

\section{A Short Overview of the Phenomenon of Export-Restraint AgreEments}

The legal and economic analysis of "grey area" measures - a scholarly endeavour to which Prof. Petersmann has offered some seminal contributions - has been carried out in several GATT documents ${ }^{8}$ and legal commentaries over the years, and need therefore be only briefly summarized here.

Export-restraint agreements have represented "economically the most distortive and politically the most dangerous form of protectionism". ${ }^{9}$ Legally speaking, they were at odds with several general principles of the GATT system. By imposing discriminatory and non-transparent export restrictions on selected products (in the form of quantitative restrictions, price undertakings, surveillance systems, export forecasts etc.) aimed at protecting the domestic market of the importing country, "grey area" measures simultaneously contravened the GATT prohibitions of quantitative restrictions (Art. XI), of their discriminatory administration (Art. XIII), and the requirement of transparency (Art. X). ${ }^{10}$ At the same time, these measures were not justified by Art. XIX - the main "escape clause" provided for by GATT in order to protect, given certain conditions, domestic producers from import surges - at least because ordinary safeguard measures need to be applied in a non-discriminatory way. ${ }^{11}$ Moreover, according to the prevailing view, ${ }^{12}$ the agreements in question, being inter se agreements concluded at variance with multilateral discipline, were unlawful under Art. 41.1.b) of the Vienna Convention on the Law of Treaties. In fact, being in contrast with several key principles of the

8 See, for instance, "Grey-Area Measures", Background Note by the Secretariat, MTN.GNG/ NG9/W/6, 16 September 1987 .

9 E.-U. Petersmann, 'Grey Area Trade Restrictions and International Law', in D. Dicke, E.-U. Petersmann (eds.), Foreign Trade in the Present and a New International Economic Order (Fribourg, 1988), p. 203.

10 Idem., Grey Area Trade Policy and the Rule of Law, 22 Journal of World Trade 1988, p. 25 ff., at p. 30 ff.; J. Jackson, Consistency of Export Restraints with the GATT, 11 The World Economy 1988, p. 485 ff.

11 See, in this sense, B. Hindlay, 'Voluntary Export Restraints and the GATT's Main Escape Clause', 3 WorldEconomy 1980, pp. 313 ff., at p. 326 ff.; M. Tatsuta, 'Voluntary Export Restraints - Implementation and Implications', 49 Rabels Zeitschrift 1985, pp. 328 ff.; I. Bernier, 'Les ententes de restriction volontaire à l'exportation en droit international économique', 11 Canadian Yearbook of International Law 1973, p. 48 ff, at p. 79 ff.; M.W. Lochmann, 'The Japanese Voluntary Restraint on Automobile Exports: An Abandonment of the Free Trade Principles of GATT and the Free Trade Market Principles of United States Antitrust Law', 27 Harvard International Law Journal 1986, p. 99 ff., at p. 120; P. Wang, 'The Japanese Automotive Voluntary Export Restraint Agreements and International Law', 23 Canadian Yearbook of International Law 1985, p. 297 ff., at p. $304 \mathrm{ff}$.

12 See E.-U. Petersmann, Grey Area Trade Policy, quoted above, pp. 31 and p. 43; R. Quick, Exportselbstbeschränkungen und Artikel XIX GATT (Köln, 1983), p. 268, and H. Moinuddin, 'Grey Area Trade Policies', in D. Dicke and E.-U. Petersmann (eds.), Foreign Trade, quoted above, p. 197 ff., p. 205. 
GATT, they were at least incompatible with the realization of the object and purpose of the treaty as a whole, as well as possibly damaging the rights of other contracting parties. And therefore illegal, but - it must be added - valid, since the peremptory nature of rules could hardly be sustained when departure from them had been widely practiced and tolerated. In this regard, suffice it to recall that from 1974 to 1994 the Multifibre Agreement was operating under the auspices of GATT 1947, and that its Article 4 openly allowed its contracting parties to enter into agreements restricting exports.

Today, the ban contained in Art. 11.1.b) AS, whereby “...a Member shall not seek, take or maintain any voluntary export restraints, orderly market arrangements or any other similar measure on the export or the import side", coupled with the phasing out of existing measures, seems therefore to have re-established the respect among Member States for the basic principles underpinning the multilateral trade system.

All's well that ends well? Apparently.

Some of the comments published immediately after the conclusion of the Uruguay Round were rather sceptical about the potential effectiveness of the ban: only "a sea-change in the mindset of the GATT Member States"13 could guarantee the solution of the VERs problem under the new regime. According to others: "symptoms rather than causes have been cured". ${ }^{14}$

Leaving aside the less confessable motives which spurred the popularity of VRAs (eg, bypassing parliamentary and judicial controls, entering into secret or non-binding governmental arrangements), the crux of the matter - as mentioned - is the greater practical convenience that characterized the measures under consideration with respect to official trade remedies offered by the GATT system $^{15}$ (especially "exceptional" safeguard measures designed to limit imports temporarily, measures not involving as a precondition unfair or illegal trade practices which distort competition, such as subsidies or dumping).

Export-restraint agreements were simply less costly for both sides; sometimes they turned out to be even profitable for them. The importing country could offer protection to domestic producers incapable of meeting international competition without, for example, having to provide proof of the presence of the complicated conditions required by GATT Art. XIX (unforeseen developments, serious injury or

13 Thus E.M. Hizon, 'The Safeguard Measure/VER Dilemma: The Jekyll and Hyde of Trade Protection', 15 Northwestern Journal of International Law \& Business 1994, p. 105 ff., at p. 138.

14 M. Bronckers, 'Voluntary Export Restraints and the GATT 1994 Agreement on Safeguards', in J. Bourgeois, F. Berrod, E. Gippini Fournier (eds.), The Uruguay Round Results. A European Lawyer's Perspective (Brussels, 1995), p. 279.

15 "... the diversion to bilateralism may be attributed precisely to the failure of the escape clause to provide a viable option", thus Hizon, supra note 13, p. 115. According to J.F. Perez-Lopez, 'GATT Safeguards: A Critical Review of Article XIX and Its Implementation in Selected Countries', 23 Case Western Reserve Journal of International Law 1991, pp. 517 ff., at p. 533, VRAs might be taken as "prima facie evidence of the failure of Article XIX". 
threat thereof etc.), at a lower cost than it would pay activating the formal safeguard mechanism. In the latter case, in fact, the importing State is required to apply the measure chosen in respect of all the suppliers of the goods affected (regardless of their nationality), in compliance with the principle of the most (dis) favoured nation. ${ }^{16}$ The lack of selectivity of authorized safeguard measures, resulting in a disproportion to the objective pursued (which is, usually, to limit exports from one country, or otherwise from a restricted number of States), multiplies the overall effect of trade restriction. Moreover, if all the countries acting as suppliers of that product are affected, the importing country has to negotiate compensation or suffer retaliation from all of them. This mechanism, which increases the cost of protection and the ensuing trade restriction, was, however, avoided through the conclusion of a bilateral, selective export-restraint agreement.

In turn, the exporting country found it convenient to acquiesce to the pressure exercised by the importing country (usually threatening the activation of trade defence measures or the adoption of protectionist legislation). While, in fact, the management of safeguard measures is entrusted to the authorities of the importing State, the administration of the quotas (or other types of measures) agreed through export-restraint arrangements is entrusted to the authorities of the exporting country. For them, or for their domestic producers, the decline in exports provides an in-built element of compensation, since they capture the "scarcity rents" which follow the artificial restriction on the supply of the product on the market of the importing country, producing an increase in the prices of the exported good. In addition, the agreements in question are usually the outcome of a negotiation, which avoids the imposition of duties or other restrictive measures by the importing country, an event that almost always produces more damage in terms of reduced quantities or higher prices of exported goods.

Obviously, such benefits have a cost in economic and commercial terms (their unlawfulness has already been mentioned). The agreements in question, in fact, are the vehicle of covert trade restrictions; they distort an efficient allocation of the factors of production both internally and internationally (to an extent, however, that decreases with the increase of the comparative advantage enjoyed by the exporter, and high comparative advantages are usually the premise of the use of the measures at issue here); they create a surplus price paid by consumers in the protected markets ${ }^{17}$ (but also erga omnes safeguards produce the same effect, and perhaps even on a bigger scale), and introduce en element of discrimination

16 This principle is not actually provided by GATT Art. XIX, but is derived from other provisions of the General Agreement, by the decisions of panels under the GATT 1947, and is now codified by Art. 2.2 of the Agreement on Safeguards.

17 See OECD, Competition and Trade Policies: Their Interaction, (Paris, 1984), p. 12. To limit ourselves to one example, Lochmann, supra note 11, pointed out that the export-restraint agreement concluded in 1981 between Japan and the United States on automobiles "raised prices for new cars by an extra 400 dollars per auto" (p. 112). 
to the detriment of developing countries. Historically, then, these agreements tend to proliferate, because the restriction of exports from country A creates space in the importing country for products from country B. This can encourage the conclusion of another export-restraint arrangement with country B. Meanwhile, the goods of country A are usually diverted to the markets of other countries. These latter may, in turn, come to be in a situation of surplus and then press to conclude a new export-restraint agreement.

Be that as it may, "grey area" measures ended up being less costly than formal safeguard measures, and very effective in avoiding trade wars. ${ }^{18}$ Furthermore, the tendency to operate for extended periods has also traditionally characterized unilateral safeguard measures, for which Art. XIX of GATT 1947 did not set a maximum duration (in contrast to what happens today, pursuant to Art. 7 AS).

Available data demonstrate the ineffectiveness of the formal mechanism of trade protection. In the nearly fifty years during which GATT 1947 has been in place, its Members have notified an average of only three formal measures per year (about 150 in total).${ }^{19}$ In early 1991, 24 formal safeguard measures were in place, while almost 300 agreements containing grey area measures were in effect, ${ }^{20}$ not counting the measures kept secret, and the entire field of textile and clothing that, since 1974, was regulated - as mentioned - through the Multifibre Agreement.

The (persisting) greater efficiency of grey area measures with respect to the formal safeguard mechanism has recently led some authors to propose their legalization under the WTO. ${ }^{21}$ From a Law-and-Economics perspective, on the other hand, an agreement restricting export may well represent an efficient breach of the relative prohibition: selective, fast, automatically compensating (and politically valuable). In contrast, of course, with the pacta sunt servanda principle, with several key principles of the WTO system and the opinions of those - like the author honoured in this Festschrift ${ }^{22}$ - who maintain the inherently constitutional nature of multilateral trade rules, but, on the other hand, perfectly in line with the principle of the general validity of inter se agreements, ${ }^{23}$ and the views of those who doubt

18 G. Burdeau, Les engagements d'autolimitation et l'évolution du commerce international, 37 Annuaire français de droit international 1991, p. $748 \mathrm{ff}$.

19 See P. van den Bossche, The Law and Policy of the World Trade Organization, 2ed., (Cambridge, 2008), p. 672.

20 GATT, Council Overview of Developments in International Trade and the Trading System, Annual Report by the Director General, C/RM/OV/1, 12 April 1991, p. 8.

21 D. Kitt, 'What's Wrong with Volunteering? The Futility of the WTO's Ban on Voluntary Export Restraints', 47 Columbia Journal of Transnational Law 2009, p. 359 ff., at p. 384.

22 See, among many other works, E.-U. Petersmann, 'The WTO Constitution and Human Rights', 3 Journal of International Economic Law 2000, p. 19 ff.; idem., 'Human Rights and International Economic Law in the 21st Century: The Need to Clarify Their Interrelationships', 4 Journal of International Economic Law 2001, p. 3 ff.

23 F. Capotorti, 'L'extinction et la suspension des traités', 134 Recueil des Cours 1971-III, p. 504. 
that the WTO has become something ontologically different from the GATT à la carte. $^{24}$

3. The Attempt to Revitalize the Safeguard Measures: A Failure So Far?

As mentioned above, the apparent ineffectiveness of the safeguard mechanism provided for by Art. XIX GATT was one of the main causes behind the proliferation of "grey area" measures. Accordingly, the revitalization of this instrument represents a key factor in making the current ban on these measures really effective.

Two innovations introduced by the Agreement on safeguards, in particular, aim to restore the effective functioning of the safeguard clause. Both are intended to remedy the high cost of its activation, arising from the obligation to apply it on an MFN basis.

In the first instance - accepting proposals made by some of the participants in the Uruguay Round (in particular by the European Union) - an element of flexibility in the application of safeguard measures has been introduced. Although the principle of non-discriminatory application of safeguards has been reiterated (Art. 2.2), and provided that the chosen form of protection does not consist in an increase in tariffs, today the State in need of protection from imports, is in fact, enabled to graduate the quantum between countries suppliers of the product. More specifically, if the exports from some Member parties have increased more than proportionally with respect to the total increase of imports of that product, then - pursuant to Art. 5.2.b) AS - it is possible to depart from the general rules on the allocation of quotas, "hitting harder" the State whose exports have been the most damaging.

Secondly, notwithstanding the option for exporting countries affected by safeguard measures to activate retaliatory measures (if no compensation is agreed upon), the right to suspend substantially equivalent concessions may not be exercised in the first three years of validity of a safeguard measure (Art. 8.3 AS). This is valid provided that the measure has been taken as a result of an absolute (not relative) increase in imports, and that it is compliant with the Agreement. In short, for three years safeguards have no cost, except for a compensation that the importing country negotiates from a position of strength.

Has the attempt to render the use of the safeguard clause more attractive been working in practice, especially in the light of the protectionists pressures unleashed by the financial crisis? In this regard, two clearly detectable trends confront each other: on the one hand, both the number of trade remedy investigations and the proportion of initiations that lead to definitive measures have been declining

${ }^{24} \mathrm{~J}$. Pauwelyn, Conflicts of Norms in Public International Law. How WTO Relates to Other Rules of International Law (Cambridge, 2003), p. 315. 
since the $2008 .{ }^{25}$ Within trade remedies, as usual, anti-dumping measures, firstly, and then countervailing duties got the lion's share compared with safeguards. On the other hand, an upward trend in the implementation of new export restrictions (affecting mainly certain raw materials and minerals and food products) has been registered, especially in the period between October 2010 and October 2011. ${ }^{26}$

More generally speaking, the judgment given by several authors on the functioning of the safeguard mechanism under the WTO is far from encouraging. As has been observed, "insurmountable hurdles to the legal use of safeguard measures"27 persist. Noting the impressive record of condemnations inflicted by the WTO dispute settlement organs in respect of the States resorting to safeguard measures (since they usually do not meet the standard of review of at least one of the legal requirements), ${ }^{28}$ it has even been argued that these measures would be permitted only in theory. ${ }^{29}$

The cause of these obstacles - in addition to definition gaps still existing in the current normative text - is mainly attributed to the overly restrictive attitude taken by the WTO dispute settlement bodies in interpreting and applying the provisions of the Agreement on Safeguards. An attitude probably justified by the fear of abuse that leads to admitting the use of safeguard measures only in emergency situations (as is made clear by the WTO case-law, ${ }^{30}$ and by the very title of Art. XIX GATT "Emergency Action on Imports of Particular Products"). After all, the GATT system has always looked to safeguard measures with a certain "sense of guilt". This largely derives from the circumstance that safeguards are designed to temporarily protect domestic industries affected by economic difficulties, since they are not able to withstand the impact of more competitive imports. From the point of view of a free trade system, however, these difficulties are the virtuous effect produced by the proper functioning of the system itself. They, in fact, indicate a transfer of comparative advantages to more efficient foreign industries that produce at

25 Overview of the Developments in the International Trading Environment, Annual Report by the Director-General, WT/TPR/OV/14, 21 November 2011, p. $23 \mathrm{ff}$.

26 Ibid, pp. 17 and 23.

27 A.O. Sykes, 'The Persistent Puzzles of Safeguards: Lessons From the Steel Dispute', 7 Journal of International Economic Law 2004, p. 523 ff. In the same vein, see also R. Bhala and D. Gantz, 'WTO Case Review 2001', 19 Arizona Journal of International \& Comparative Law 2002, p. 457 ff., at p. 630, and J.R. Schick, 'Agreement on Safeguards: Realistic Tools for Protecting Domestic Industry or Protectionist Measures?', 27 Suffolk Transnational Law Review 2003, p. 153 ff.

28 C. Stevenson, 'Are World Trade Organization Members Correctly Applying World Trade Organization Rules in Safeguard Determinations?', 38 Journal of World Trade 2004, p. 307 ff.

29 Y. Guochua, 'Are Safeguard Measures Permitted Under the World Trade Organization System?', 17 Temple International and Comparative Law Journal 2003, p. 175 ff.

30 See the Appellate Body's assessment in Korea - Definitive Safeguard Measure on Imports of Certain Dairy Products, WT/DS98/AB/R, 14 December 1999, para. 86 ("the text of Article XIX:1(a) of the GATT 1994, read in its ordinary meaning and in its context, demonstrates that safeguard measures were intended by the drafters of the GATT to be matters out of the ordinary, to be matters of urgency, to be, in short, "emergency actions"”). 
lower costs (for reasons not always commendable, sometimes associated with lower standards of social protection). Compared with trade defence measures (anti-dumping or countervailing duties), which are directed against unfair or illegal practices, safeguard measures are then inevitably experienced by the multilateral trading system with a certain suspicion, because they represent a contradiction, which is tolerated mainly to allow States to offset the gradual removal of trade barriers with domestic interests.

The strict attitude taken by WTO dispute settlement bodies is notoriously reflected in the solution adopted by the Appellate Body regarding the relationship between Art. XIX GATT and the Agreement on Safeguards (in Korea - Dairy Product, ${ }^{31}$ and then in Argentina - Footwear). ${ }^{32}$ According to this case-law, indeed, the factual and legal requirements provided by both sources have to be applied cumulatively, which means that the importing State may be called to prove that the serious injury (actual or threatened) suffered from domestic producers because of a high increase in imports depends on two conditions ("unforeseen developments" and obligations undertaken by virtue of the participation in the GATT), which are provided for only by Art. XIX GATT, while the Agreement on safeguards does not mention them. The reintroduction by the Appellate Body of the "unforeseen developments" requirement creates further problems in the absence of a detailed regulation: it is not clear, for example, what the "critical date" is on the basis of which one must consider whether or not the developments were unexpected. And no less interpretative difficulties are created by other requirements imposed by the Agreement in question. What exactly does it mean that the increase in imports, as stated by the Appellate Body in Argentina - Footwear, must be "recent enough, sudden enough, sharp enough, and significant enough, both quantitatively and qualitatively, to cause or threaten to cause serious injury"? 33 What does "enough" mean, and to what must the increase of imports amount? What is the relative importance of each of the eight factors on which one must calculate whether there has been a serious injury? What exactly is the method by which one must reconstruct the causal link between increased imports and serious injury? And so on.

The obvious fear is that by weighting the burden of proof imposed on the country in need of protection in situations of economic difficulty, resorting to exportrestraint agreement might again be encouraged.

31 Ibid., para. 77 ("any safeguard measure imposed after the entry into force of the WTO Agreement must comply with the provisions of both the Agreement on Safeguards and Article XIX of the GATT 1994").

32 Appellate Body Report, Argentina - Safeguard Measures on Imports of Footwear, WT/DS121/ $\mathrm{AB} / \mathrm{R}, 14$ December 1999, para. 83 .

33 Ibid., para. 131. 


\section{Some Intrinsic and Extrinsic Limits of the Ban of "Grey Area" \\ Measures: The Exclusion of Private Arrangements and THE PROBLEM OF ITS ENFORCEABILITY}

Apart from its exceptions - a subject that will be dealt with in the next paragraphs - perhaps the greatest weakness affecting the ban contained in Art. 11 AS lies in the fact that it does not apply to "non-governmental measures", i.e., arrangements concluded between private undertakings without any involvement of governmental or other kind of public authorities. The reason for this exclusion is that the WTO rules aim essentially to regulate the conduct of Member States. Export or import cartels or trade-disruptive industry-to-industry arrangements do not, therefore, come under the prohibition at issue here. This element is likely to stimulate a shift from public to private agreements concluded at an exclusive industry level. ${ }^{34}$

In this regard, the only relevant provision is enshrined in Art. 11.3 of the Agreement on Safeguards, and prohibits States "to encourage or support the adoption or maintenance by public and private enterprises of non-governmental measures equivalent to those referred to in paragraph 1 ".

The real content of this obligation has become the subject of an interesting scholarly debate. For some authors, the duty not to encourage or support involves only a negative obligation of non facere. ${ }^{35}$ For others, however, it must be read as including also the obligation not to tolerate arrangements between private enterprises, and therefore a positive obligation of facere consisting, for instance, in the duty to enact and enforce domestic antitrust laws. ${ }^{36}$ This second view, mostly based on a teleological reading of the Agreement on Safeguards (which should be interpreted as aimed at avoiding any adverse effect on competition), ${ }^{37}$ seems to be contradicted by the text of Art. 11.3 AS and by the circumstance that the WTO does not yet regulate competition policies. Nothing in the Agreement on Safeguards, nor in any other WTO provision, may be read as imposing on Member States the duty to enact and implement domestic competition laws in order to impede private VERs.

A second major problem - this time of an external nature - concerns the enforceability of the ban enshrined in Art. 11.1.b) AS. As is well known, the WTO dispute settlement system lacks any form of control "from above", by

34 See Negotiating Group on Safeguards, Meeting of 30 October, 1 and 2 November 1989, MTG. GNG/NG9/13, 12 December 1989 .

35 F. Wolfram, Art. 11 of the Agreement on Safeguards, in R. Wolfrum, P.T. Stoll, M. Koebele (eds.), WTO-Trade Remedies, Max Planck Commentaries on World Trade Law (Leiden, Boston, 2008), p. 375 ff., at p. 386; Y.-S. Lee, Safeguard Measures in World Trade. The Legal Analysis (Leiden, The Hague, 2005), p. 117, footnote 491, and p. 121.

36 P. Didier, WTO Trade Instruments in EU Law (London, 1999), p. 346.

37 S. Nüesch, Voluntary Export Restraints in WTO and EU Law (Bern, 2012), p. 280 ff. 
the organization (which has not been given the power to initiate proprio motu proceedings against its Members), or "from below", by private operators. This is crucial, because the real losers from VERs are the consumers facing higher prices and fewer choices of the product in question. At international level, they are not entitled to lodge a direct complaint against a State that has concluded a WTOinconsistent export-restraint agreement. The only indirect avenue is provided by those administrative mechanisms, such as the US Section 301 and the EU Trade Barriers Regulation, according to which private parties play a triggering role, which however remain dependent on the will of the respective executive bodies to finally lodge a WTO complaint. At domestic level, then, the absence of direct effect of WTO rules in the legal order of the main users of these measures (EU, USA, Canada, Japan) stands in the way of the possibility for private parties to invoke the WTO-inconsistency of prohibited agreements before national courts.

Finally, the traditional problem of concentrated benefits and dispersed costs plays an important role in this field, creating powerful incentives to lobby for protectionist measures.

In sum, the only real opportunity to submit these measures to judicial control is left to the decision of WTO Member States, which however have never seemed very interested in following this path. Export-restraint agreements, in fact, constitute a win-win situation, beneficial for both the importing and exporting countries. It is therefore highly unlikely that any of the contracting parties may find it convenient to bring a complaint before the WTO dispute settlement bodies to claim an illegality to which it has given its consent (volenti non fit iniuria). The only possibility that theoretically would remain open is a complaint filed by a third WTO Member suffering from an effect of trade-diversion induced by an exportrestraint agreement concluded between two other WTO Members. However, the circumstance that only on very rare occasions have GATT panels been called to pronounce themselves on these measures, ${ }^{38}$ and that so far no complaint has been brought to the WTO dispute settlement bodies in this field, demonstrates that WTO Member parties - apart from the difficulty of obtaining detailed information on these agreement and demonstrating the existence of serious harm have in turn preferred to conclude further arrangements to protect the competitive chances of their domestic industries.

The bottom line is that the circumstance that the judicial enforcement of WTO rules relies exclusively on complaints brought by its Members transforms the "grey area" into a "safe area", in which illegal behaviour is not easy to detect. ${ }^{39}$

38 See the panel's reports in Norway - Restriction on Imports of Certain Textile Products, BISD 1981, Suppl. 27, p. 119 ff.; EEC - Restrictions on Imports of Apples from Chile, BISD 1981, Suppl. 27, p. 98 ff.; Japan - Trade in Semi-Conductors, BISD 1989, Suppl. 35, p. $116 \mathrm{ff}$.

39 For further analysis on this issue, see Nüesch, Voluntary Export Restraints, quoted above, passim. 
Several proposals have been put forward to remedy this situation. They range from the establishment of a "WTO attorney general",40 to granting private parties and NGOs the right to participate in WTO proceedings by notifying the existence of grey area measures ${ }^{41}$ to the revitalization of the surveillance role of the Committee of Safeguards, that should closely monitor the implementation of the ban contained in Art. 11 and report any suspected violation to the Council for Trade in Goods. ${ }^{42}$

5. The Persistent Use of Export-Restraint Agreements Falling within the Exceptions to the Ban Provided by Art. 11. 1. C) AS: The Case of the Protocol of Accession of China and the Agreement Restricting THE EXPORT OF CHINESE TEXTILES

In a sense, the emergence of "grey area" measures is a by-product of the accession of Japan to the GATT, in 1955. At that time, many industrialized countries feared that Japanese manufactured goods produced at much lower costs (and thus sold at a much more competitive price) could flood their markets. This led many governments (especially those of European countries) to initially oppose the accession of Japan. In fact, the widespread belief was that the safeguard clause enshrined in Art. XIX GATT was totally inadequate to cope with that situation, because it did not lend itself to a discriminatory application directed exclusively towards Japanese products. An attempt was made to obtain a special safeguard, derogating to Art. XIX GATT, but no concrete result was achieved..$^{43}$ The result was that Japan acceded to the GATT in September 1955, and that 14 Member Countries (which accounted for $40 \%$ of the volume of Japanese exports) invoked Art. XXXV GATT to prevent the application of GATT rules in their relationships with the new Member. To induce some of these countries to modify their decision, the Japanese authorities showed that they were willing to extend to relations with these States the practice of voluntary agreement limiting exports, already begun with the United States in 1957. In the mid-6os, Japan had concluded agreements of this kind with twenty countries. ${ }^{44}$ A special safeguard measure affecting a single industrial sector - cotton textiles - was incorporated firstly in the Short-Term Agreement of 1961, then replaced in 1962 by the Long-Term Agreement, and finally in 1974 in the Multifibre Agreement, a veritable "factory" of grey area measures. Export-restraint

40 Y.K. Kim, 'The Beginning of the Rule of Law in the International Trade System despite U.S. Constitutional Constraints', 17 Michigan Journal of International Law 1996, pp. 967 ff., p. 992, footnote 136.

${ }^{41}$ Lee, Revival, supra note 7, p. 163.

42 Lee, Safeguard Measures, supra note 35, p. 119.

43 See G. Patterson, Discrimination in International Trade. The Policy Issues 1945-1965 (Princeton, 1966), pp. $281 \mathrm{ff}$.

44 Ibid., p. 296. 
agreements were negotiated also to curb exports from other developing countries, like Pakistan, India and Hong Kong.

Nearly a century later, a similar problem arose in anticipation of China's accession to the WTO (accession that took place in November 2001). This time it was immediately decided to set up a special system of safeguards, that also provides for measures limiting exports. To this end, one of the exceptions that Art. 11.1 c) AS imposes on the ban of measures limiting exports turned out to be useful. Under this provision, in fact "The Agreement does not apply to measures sought, taken or maintained by a Member pursuant to provisions of GATT 1994 other than Article XIX, and Multilateral Trade Agreements in Annex IA other than this Agreement, or pursuant to protocols and agreements or arrangements concluded within the framework of GATT 1994" (emphasis added). Among the protocols whose conclusion is provided for by Art. XXXIII GATT, there are those through which the government of a third country negotiates the terms of its accession to the General Agreement. Today, as accession is no longer only to the GATT but to the whole package of agreements administered by the WTO, the procedure is also regulated under Art. XII of the Agreement Establishing the WTO. This rule confirms that accession takes place "on terms to be agreed" between the WTO and the acceding State.

Well, Art. 16 of the Protocol laying down the conditions for the accession of the People's Republic of China (hereinafter China) creates a transitional safeguard mechanism that applies only to the products of that country (exactly what was sought, and not achieved, at the time of the accession of Japan), and operates for a period of twelve years from the date of China's accession (until the end of 2013). ${ }^{45}$ This special mechanism differs from the common discipline, enshrined in Art. XIX GATT and in the Agreement on Safeguards, in numerous respects. They concern, inter alia, the extent of the injury (which must not be "serious", but only cause a market disruption, and thus only "material"), the possibility of resorting to countermeasures by China (which is forbidden for two years, even in the case of relative increases in imports), and the duration of safeguard measures (which is not determined). ${ }^{46}$ For our purposes, however, the most characteristic point of the "Transitional Product-Specific Safeguard Mechanism" is governed by Art. 16.2 of the Protocol of Accession. Under this provision "If in the course of these bilateral consultations, it is agreed that imports of Chinese origin are such a cause and that action is necessary, China shall take such action as to prevent or remedy the market disruption" (emphasis added), which is equivalent to a rather unveiled call for the adoption of measures aiming to restrict imports. But there is more.

45 For the text of this Protocol, see WTO Doc. WT/L/432, 23 November 2001.

46 For a wider analysis, see Y.S. Lee, 'The Specific Safeguard Mechanism in the Protocol on China's Accession to the WTO. A Serious Step Backward from the Achievement of the Uruguay Round', 5 Journal of World Intellectual Property 2002, p. $219 \mathrm{ff}$. 
In addition to the transitional safeguard mechanism just analysed, the negotiations that preceded the accession of China produced another safeguard mechanism, which might be labelled "super-special", as it affects not only Chinese products, but only one category of products (textiles). This mechanism is governed by Art. 242 of the Report of the Working Party on the Accession of China ${ }^{47}$ (whose terms and conditions are part of the Protocol of Accession, an instrument which, in turn, becomes part of the WTO agreements after its ratification by the applicant State). It remained formally in force until 31st December, 2008.

The reason behind the introduction of this additional safeguard measure lies in the gradual phasing out of quotas on textiles under the Multifibre Agreement. It is widely known that with the entry into force of the Uruguay Round Agreements, the Multifibre Agreement was replaced and superseded by the WTO Agreement on Textiles and Clothing, with the objective of a gradual reintegration of the relative sector within the multilateral trade regime. After ten years, the Agreement on Textiles and Clothing ceased to be in force (on January 2005). After the expiry of the transitional regime governed by this Agreement, all the quotas previously in force ceased to have effect, so that Chinese textiles encountered no obstacle in invading the markets of most industrialized countries. To pave the way for a transition as smooth as possible, at the beginning of 2005, China adopted some "voluntary" measures of export restrictions. The failure of this solution, however, pushed to activate the means that had been prudently set up in the Report of the Working Party on the Accession of China. In short, Art. 242 of the Report creates a mechanism of consultations within which "Every effort would be made to reach agreement on a mutually satisfactory solution.... However, already upon receipt of the request for consultations, China automatically undertakes to limit its exports to a level not exceeding $7.5 \%$ (that becomes $6 \%$ for wool products) of the amount of exports recorded in the 12 months preceding the request for consultations. In itself, this measure already shows the distinctive features of exportrestraint agreements.

It was then the practice to take charge of clarifying what was meant by consultations aimed at reaching a "mutually satisfactory solution" that can reduce or avoid market disruption. On June 11, 2005, in fact, the European Union and China concluded a Memorandum of Understanding ${ }^{48}$ providing for the imposition of export quotas on ten categories of Chinese textiles, whose duration was extended until the end of 2007. ${ }^{49}$ In August 2005, the maximum quota established for some

\footnotetext{
47 Report of the Working Party on the Accession of China, WT/ACC/CHN/49, 1 October 2001, p. $45 \mathrm{ff}$.

48 For the content of this Memorandum, see EU-China Textile Agreement 10 June 2005. Memo, at www.trade.ec.europa.eu/doclib/docs/2005/june/tradoc_123754.pdf.

49 Recitals 3 and 6 of the Preamble to Commission Regulation (EC) No 1084/2005 of 8 July 2005 amending Annexes II, III and V to Council Regulation (EEC) No 3030/93 on Common Rules for Imports of Certain Textile Products from Third Countries (in OJEC L177/19, 9 July 2005) makes it clear that
} 
products was quickly reached, a situation that caused an embargo on the clearance of Chinese textiles, which remained stowed in the warehouses of European ports. To allow for clearance, on 5 th September 2005, the parties agreed on some transitional measures of flexibility regarding the implementation of the previous agreement. ${ }^{50}$

The same route was followed by the United States. Following a traditional pattern of conduct, this country aggressively invoked trade defence instruments to put pressure on China and push the conclusion of an overall agreement. ${ }^{51}$ On 8th November 2005, the United States and China stipulated a Memorandum of Understanding concerning trade in textiles and clothing. ${ }^{52}$ The agreement imposed export restrictions on 21 categories of Chinese textile products with effect from 1 January 2006 until 31 December 2008.

Thus, from the time of its accession to the WTO and until the dates of expiry of the measures analysed, China has been subject to a system of safeguards (doubly) special, highly divergent compared to that commonly in effect. This regime allows the use of agreements limiting exports, taking advantage of one of the exceptions to the prohibition of "grey area" measures enshrined in Art. 11.1 c) AS. Under Art. 41.1.a) of the Vienna Convention on the Law of Treaties this is, therefore, a hypothesis in which the inter se agreement is "provided for" by the multilateral treaty. In this regard, however, there is something important to be noted.

In the legal scholarship, ${ }^{53}$ in fact, it has been observed that in cases in which the inter se agreements are provided for by the general agreement, they should be considered "by definition" compatible with the object and purpose of the multilateral treaty as a whole. That is, by virtue of a sort of parallelism with the hypothesis disciplined sub Art. 41. 1.b), i.e., one in which the modification is neither provided for nor prohibited, and therefore must comply with the object and purpose of the general agreement as a whole (as well as with other parties' rights) to be considered lawful. To confirm this, mention is often made of some treaty-provisions (for example, Art. $5^{2}$ of the Charter of the United Nations, or Art. 31 of the UN Convention on the Law of the Sea) which allow the conclusion of further

paragraph 242 of the Working Party Report on the Accession of the People's Republic of China is the legal basis for the conclusion of such Memorandum.

50 This agreement was implemented in the EC legal order through Commission Regulation $(E C)$ No. 1478/2005 of 12 September 2005 amending Annexes V, VI e VII to Council Regulation (EEC) No. 3030/93 on Common Rules for Imports of Certain Textile Products from Third Countries (in OJEC L 236/3, 13 September 2005).

51 See V.C. Jones, Safeguards on Textile and Apparel Imports from China, CRS Report for Congress, 30 June 2006, available at http://italy.usembassy.gov/pdf/other/RL32168.pdf.

52 The text may be found at: www.pro-logistics.com/Pro-Links/Mem\%20of\%2oUnderstanding \%2obetween\%2oUSA\%20and\%2oPRC\%20\%2011-15-2005.pdf.

53 See A. Rigaux and D. Simon, 'Article 41', in O. Corten and P. Klein (eds.), Les Conventions de Vienne sur le droit des traités. Commentaire article par article (Bruxelles, 2006), p. 1561 ff., p. 1574. 
agreements, but only on condition that they fulfil the object and purpose of the multilateral treaty and /or its fundamental principles.

Reverting now to our subject, it is evident that the hypothesis just mentioned does not occur in the case of agreements limiting exports whose conclusion is provided or allowed by the Protocol of Accession of China to the WTO, and therefore allowed under Art. 11.1.c) AS. These agreements, in fact, for reasons given above (see para. 2), are certainly at odds with fundamental principles and the object of the multilateral trading system. And this is perhaps the most interesting element, because it shows that a legal system can end up allowing exemptions to its core principles to absorb a potential situation of systemic crisis (as was the entry into the WTO of a commercial "giant" like China).

On the other hand, the story of the special safeguard regime transiently prepared for Chinese products - especially when viewed within the broader context of the so-called WTO-plus obligations accepted, in some cases permanently, by China ${ }^{54}$ - highlights how fragmentation is not so much (or only, if one prefers) a contradiction that the WTO raises vis-à-vis the international legal order taken as a whole, but an internal dynamics of the multilateral trade legal subsystem. Moreover, as has been openly advocated by some Member States of the WTO, the fact that according to Art. XII of the Agreement Establishing the WTO, the conditions of accession should be negotiated case by case, and without any defined limit or condition, means that "the acceding governments do not have the automatic right to the treatment laid down in the WTO Agreements for original Members of the WTO". ${ }^{55}$ An assertion that seems to contradict those views according to which "WTO obligations are always the same for all Members". ${ }^{56}$

Obviously, one could observe that the WTO system provides for the principle of preferential and differentiated treatment. This treatment, however, is designed to help developing countries, so as to achieve one of the objectives stated in the Preamble to the Agreement establishing the WTO (“... to ensure that developing countries, and especially the least developed among them, secure a share in the growth in international trade commensurate with the needs of their economic development"). The agreements imposing restrictions on exports from China as the price of its entry into the WTO seem, however, to pursue the contrary aim.

${ }^{54}$ On this issue, see J. Qin, 'WTO-Plus Obligations and Their Implications for the World Trade Organization Legal System. An Appraisal of the China Accession Protocol', 37 Journal of World Trade 2003, p. 483 ff.

${ }_{55}$ Technical Note on the Accession Process. Note by the Secretariat, WT/ACC/7/Rev.2, 1 November 2000, p. 21.

56 G. Marceau, 'Conflicts of Norms and Conflicts of Jurisdictions. The Relationship between the WTO Agreement and MEAs and Other Treaties', 35Journal of World Trade 2001, p. 1081 ff., at p. 1105. 


\section{The Persistent Use of Export-Restraint Agreements Falling Outside} the SCope of Exceptions to the Ban Provided by Art. 11. 1. C) OF the

Agreement on Safeguards: The Steel Agreements

Reiterating provisions already existing in the Codes adopted under the Tokyo Round, Art. 18 of the WTO Agreement on Subsidies and Countervailing Measures (hereinafter ASCM), and Art. 8 of the Anti-Dumping Agreement (i.e., the Agreement on Implementation of Art. VI of the GATT 1994 - hereinafter ADA) establish that the procedures of investigation may be suspended or terminated without the imposition of provisional measures or countervailing/anti-dumping duties "upon receipt of satisfactory voluntary undertakings".

In the case of subsidies - which are measures attributable to States - the undertakings in question may be assumed by the government of the exporting Member as well as by private exporters (in this latter case, the consent of the exporting WTO Member is required under Art. 18.2 ASCM). In the first hypothesis: "the government of the exporting Member agrees to eliminate or limit the subsidy or take other measures concerning its effects" (emphasis added); in the second: "the exporter agrees to revise its prices so that the investigating authorities are satisfied that the injurious effect of the subsidy is eliminated...".

On the other hand, in the case of anti-dumping proceedings, Art. 8.1 ADA provides that the undertakings may be adopted exclusively "from any exporter to revise its prices or to cease exports to the area in question at dumped prices so that the authorities are satisfied that the injurious effect of the dumping is eliminated". When the undertaking is assumed directly by private exporters, thus, it aims essentially to increase the prices of exported goods in order to curb the quantity of exports.

Both hypotheses just mentioned are covered by the general clause of exception to the ban of export-restraint agreements enshrined in Art. 11.1.c) AS, as this clause covers all the measures that are authorized by the agreements listed in Annex $1 \mathrm{~A}$ (and therefore also by the Agreements on Subsidies and Anti-Dumping).

The role played by these exceptions is particularly relevant. Traditionally, and also during the current economic crisis (as we have already seen), the adoption of anti-dumping and countervailing duties is much more frequent than the activation of safeguard measures. The choice of countervailing duties and anti-dumping measures in lieu of safeguard measures (a sort of "regime shopping"), in fact, has certain advantages: selectivity, absence of authorized retaliation (because one defends itself against unfair or illegal practices), a lower threshold of harm to be proved ("material", and not "serious" injury). One must add to this the possibility of legally entering into export-restraint arrangements, provided that certain conditions are met. As already anticipated,${ }^{57}$ the risk is that the ban on "grey area"

\footnotetext{
57 M. Bronckers, Voluntary Export Restraints, supra note 14, p. 276.
} 
measures contained in the Agreement on Safeguards could push more trade frictions in the area of anti-dumping and countervailing measures, to the detriment of the exporting countries.

This forecast seems to have actually been translated into reality.

In recent years, in fact, both the United States and the European Union have concluded bilateral agreements on steel products involving "grey area" measures. 58

In 1998, for example, the U.S. authorities initiated countervailing duties investigations to determine whether Brazilian exports of certain hot-rolled flat-rolled carbon quality steel products received subsidies. On 7 th July 1999, under threat of the imminent imposition of countervailing duties, Brazil signed an agreement with the United States to suspend the investigation. ${ }^{59}$ Brazil undertook not to provide new or additional export or import substitution subsidies on steel products (Art. III), and to restrict the volume of direct or indirect exports to the United States (Art. IV). Moreover, the agreement included systems for export license (Art. V), and monitoring (Art. VII). This agreement was terminated in September 2004. In addition to the countervailing duty suspension agreement, the U.S. and Brazil also concluded an anti-dumping suspension agreement involving a minimum import price imposed on Brazil (agreement terminated in February 2002). 60

The question here arises of whether the U.S.-Brazil agreement falls within the exceptions to the ban of "grey area" measures mentioned at the beginning of this paragraph. The answer tends to be in the negative, ${ }^{61}$ because Art. 18 ASCM provides for three distinct possibilities when it allows the suspension or termination of proceedings on the basis of voluntary undertakings under which the government of an exporting Member agrees "to eliminate or limit the subsidy or take other measures concerning its effects" (emphasis added). In other words, the possibility of undertaking these obligations cumulatively seems to be clearly excluded. ${ }^{62}$ Brazil had already agreed to eliminate the subsidies, so that there was no need to take additional measures, such as export quotas, concerning the effect of the subsidized exports.

58 For a more detailed overview, see R. Grynberg, Newton, Parimal, Mpande, Bilateral Commodity Agreements - New Generation Grey Area Measures? A Scoping Study, April 2006 (at www.the commonwealth.org/Shared_ASP_Files/UploadedFiles/A29Fo339-53AA-41Ao-85A3-DE5E86FC5240 _BilateralCommodityAgreements.pdf).

59 See S.D. Murphy, 'Contemporary Practice of the United States Relating to International Law', 93 American Journal of International Law 1999, pp. 900-901. For the text, see Federal Register, vol. 64, no. 137, 19 July 1999, p. 38798 ff. (available at www.gpo.gov/fdsys/pkg/FR-1999-07-19/pdf/99-18227.pdf).

60 For the text, see ibid., p. 38793 ff. (available at www.gpo.gov/fdsys/pkg/FR-1999-07-19/pdf/ 99-18226.pdf).

61 Some U.S. steel companies qualified the agreement as being "contrary to applicable law" (www .apnewsarchive.com/1999/U-S-Brazil-Reach-Steel-Deal/id-fa396b9c7144d5e8c4be32b12129092b).

62 In this sense, Grynberg, Newton, Parimal, Mpande, Bilateral Commodity Agreements, supra note 58 , p. 17 . 
Another case in point is the U.S.-China steel agreement. On 24 October 1997, following anti-dumping investigations by the U.S. with respect to cut-to-length carbon steel from China, the two governments signed an anti-dumping investigation suspension agreement, ${ }^{63}$ which continued to be in force until 2002 (after China's accession to the WTO) and was then extended until November 2003. ${ }^{64}$ This agreement provided for quantitative restrictions of Chinese exports to the U.S. of steel exports (Art. III). Further, it included a reference price mechanism (Art. IV), and export licenses (Art. V). According to paragraph 17 of the Protocol on China's accession to the WTO "All prohibitions, quantitative restrictions and other measures maintained by WTO Members against imports from China in a manner inconsistent with the WTO Agreement are listed in Annex 7. All such prohibitions, quantitative restrictions and other measures shall be phased out or dealt with in accordance with mutually agreed terms and timetables as specified in the said Annex". Unfortunately, the United States have not specified any reservation in any commodity in Annex 7 to the China's Protocol of Accession. Therefore the quantitative restrictions maintained after the accession of China are discriminatory and in violation of article I and XIII of the GATT.

As for the EC, the authorities in Bruxelles signed two bilateral agreements on steel with Macedonia in 2002, and with Moldova in 2004, to double-check. The Agreement with Moldova ${ }^{65}$ does not involve quantitative restrictions, but provides for surveillance and export license documentation, measures that fall within the illustrative list of prohibited "grey area" measures contained in footnote 4 to Art. 11.1.b) AS.

\section{7. (SEQUitur): THE 1996 AND 2006 AgREEMENTS BETWEen the U.S. AND CANADA ON SOFTWOOD LUMBER}

The trade dispute on softwood lumber that, since 1982, opposes the United States and Canada may be regarded as an example of regime shopping. In fact, a case substantially involving the detrimental increase in the volume of imports of Canadian lumber in the United States, that could have naturally been addressed in the context of the safeguard measures provided for by Art. XIX GATT, has been strategically tackled by the U.S. authorities primarily as a problem of subsidies granted to producers of softwood lumber from Canadian authorities, and then as a case of dumped sales by the producers themselves. ${ }^{66}$ In this regard, the

63 The text may be read in Federal Register, vol. 62, No. 223, 19 November 1997, p. 61774 ff. (available at www.gpo.gov/fdsys/pkg/FR-1997-11-19/pdf/97-30394.pdf).

64 For further details, see www.ia.ita.doc.gov/frn/2003/0310frn/03-26530.txt.

65 Council Regulation (EC) No 1762/2004 of 27 September 2004 on administering of the doublechecking system without quantitative limits in respect of the export of certain steel products from the Republic of Moldova to the European Community (in OJEU L315/1, 14 October 2004).

66 On this, see G. Gagné, 'The Canada-US Softwood Lumber Dispute. A Test Case for the Development of International Trade Rules', $5^{8}$ International Law Journal 2003, p. 335 ff., at pp. 366-367. 
traditional accusation by the U.S. against Canada is that the charges that producers pay directly to the Canadian provinces (since the land is publicly owned) to cut down the trees are artificially lower than the market value (in particular with comparison to what is paid by U.S. producers that cut wood on private land). That would produce a de facto subsidiarization effect to the benefit of Canadian producers.

Against this background, agreements restricting the exports of Canadian softwood lumber in the United States were concluded in 1996 and 2006. Even here, then, the problem arises whether these measures could be considered as legally adopted in the light of the exception contained in Art. 11. 1 c) AS, referring this time to Articles 8 ADA and 18 ASCM.

More specifically, Art. II of the Softwood Lumber Agreement concluded between the United States and Canada in May $19966^{67}$ provided for the establishment by the Canadian authorities of a system of export permits (one of the "grey area" measures illustratively listed in the Agreement on Safeguards). Granting these permits became subject to the payment of a fee when the amount of softwood lumber exported to the U.S. market exceeded a certain annual amount. In return, the United States undertook not to initiate any trade action against the imports of Canadian softwood lumber. The imposition of export restraints by way of export fees was clearly intended to cause an increase in prices and, therefore, a restriction to the amount of Canadian lumber exported to the U.S. market. The Agreement was not notified to the Committee on Safeguards, and, in any case, it remained in force until March 2001, past the deadline by which all existing grey-area measures had to be phased out.

A few days after the expiry of the Softwood Lumber Agreement, U.S. lumber producers' associations readily reactivated internal procedures of investigations. The result was the start of the fourth stage of the dispute, during which Canada brought complaints before the WTO and NAFTA dispute settlement bodies, and before U.S. Courts against the proceedings and the anti-dumping/countervailing duties imposed by the U.S. authorities. ${ }^{68}$ This stage of the dispute culminated on 12 September 2006 in the conclusion of a further agreement between the United States and Canada. This time, the agreement was notified to the WTO Dispute Settlement Body under Art. 3.6 of the WTO Dispute Settlement Understanding, as a "mutually agreed solution". ${ }^{69}$ The 2006 Agreement, which is expected to last seven years, establish that the U.S. will phase out countervailing and anti-dumping

67 The text is reproduced in 35 International Legal Materials 1996, p. $1195 \mathrm{ff}$.

68 For an overview on the dispute, see C. Carmody, 'Softwood Lumber Dispute (2001-2006)', 100 American Journal of International Law 2006, p. 664 ff.; G. Gagné, 'Policy Diversity, State Autonomy, and the US-Canada Softwood Lumber Dispute: Philosophical and Normative Aspects', 41 Journal of World Trade 2007, p. 699 ff., and D. Quayat, 'The Forest For the Trees: A Roadmap to Canada's Litigation Experience in Lumber IV', 12 Journal of International Economic Law 2009, p. $115 \mathrm{ff}$.

69 For the text, see WTO Doc. WT/DS257/26, 16 November 2006. 
duties that have been applied since May 2002 against Canadian lumber export. In addition, the U.S. undertook to return to the Canadian authorities the amount of collected duties kept under deposit, along with the commitment not to start new investigations for the duration of the Agreement (Articles III, IV and V, respectively). In return, the Canadian authorities undertook to implement a dual mechanism in order to restrict their exports of lumber to the United States (Art. VII). The Canadian provinces that choose option A are required to impose a tax on exports, whose value increases with the decrease of the price of lumber sold in the U.S. market. The provinces that, instead, choose option B, in addition to a lower tax, have to impose a quota on the maximum quantity of lumber that can be exported. Both the amount of the tax and of the quota obviously increases with the decreasing price of lumber in the U.S. market, so as to counteract the alleged effect of price decline caused by subsidies or dumped prices, and thus render the exported product less competitive.

Such agreement does not appear to fall squarely within the scope of Articles 8 ADA and/or Art. 18 ASCM. Indeed, the purpose of these provisions is to create a third alternative to the two traditional outcomes that investigations on trade defence measures can usually reach. ${ }^{70}$ Beyond the rejection or, rather, the acceptance of a demand for duties, in fact, the possibility is added to suspend or terminate the relative investigation as a consequence of the giving and acceptance of voluntary undertakings, without the application of provisional measures and duties. In the case at issue here, however, definitive duties had been levied and collected for over four years, to the point that the U.S. authorities undertook in 2006 to phase them out and to return a part of them to Canada. In addition, Art. 8 ADA provides for the conclusion of agreements only between the importing State and private exporters, not between WTO Member States (as may happen, instead, in the case of subsidies).

This assessment would be different if, as some authors have maintained, ${ }^{71}$ the two provisions at issue here would implicitly allow the parties to settle the dispute through export-restraint arrangements at any time. This view cannot be shared, ${ }^{72}$ given the fact that exceptions have to be interpreted restrictively, and that no precise legal basis supporting this opinion is offered. Quite the contrary, the footnote contained in Articles 8.1 ADA and 18.1 ASCM makes it clear that there is no possibility of "the simultaneous continuation of proceedings with the implementation of price undertakings" or "... with the implementation of undertakings", which

70 See P. Picone and A. Ligustro, Diritto dell'Organizzazione mondiale del commercio (Padova, 2002), p. 250, and V. Di Comite, Le sovvenzioni e le misure compensative nell'Organizzazione mondiale del commercio (Padova, 2009), p. $291 \mathrm{ff}$.

71 J. Jackson, Consistency, supra note 10, p. 496 (this Author, however, made reference to the Codes adopted during the Tokyo Round).

72 See, in this sense, S.V. Potter, 'The Softwood Lumber Agreement of 20o6: Worth Saving?', 13 International Trade Law and Regulation 2007, p. 98 ff., at p. 101. 
may be taken to confirm that the acceptance of an undertaking and the imposition of duties are alternative solutions.

If the above is true, then also the condition laid down in Art. 3.5 DSU - under which all mutually agreed solutions (the 2006 agreement was notified precisely in this capacity) must be respectful of the WTO Agreements - is not fulfilled. Here, therefore, we are faced with an agreement that is prohibited under the WTO legal system (once the exception has been discarded, in fact, the general ban comes back into force). Moreover, like all agreements restricting exports, it collides with the object of the GATT/WTO legal system as a whole. An agreement that, therefore, does not meet two of the three requirements enshrined in Article 41.1.b) of the Vienna Convention on the Law of Treaties. Given that the consequence of an inter se agreement not fulfilling the conditions provided herein must be reconstructed in terms of responsibility towards the other parties of the general treaty, and not of invalidity, it is of great importance that no other WTO Member is reported to have raised any objection to the legality of the agreement in question before the WTO Dispute Settlement Body.

\section{Summary AND CONCLUding REMARKS}

After having defined "grey area" measures and given a brief account of the reasons for their proliferation under the GATT 1947 (reasons linked, inter alia, to the "failure" of the general safeguard clause under Art. XIX GATT), this work has examined the dual strategy through which the WTO Agreement on Safeguards intended to reintegrate these measures within the WTO system of legality (by forbidding export-restraint agreement, on the one hand, and trying to revive legal safeguards on the other). According to several authors, the achievement of this goal is currently frustrated by the overly restrictive attitude adopted by the WTO dispute settlement bodies. Moreover, by imposing the ban of export-restraint agreements, the Uruguay Round negotiators have provided exceptions whose scope - as has been demonstrated by China's Protocol of Accession to the WTO in 2001 - have turned out to be very broad. Exceptions that still leave open the possibility for Member States to restrict exports through voluntary undertakings taken as a consequence of investigations concerning trade defence measures. Finally, even if none of the exceptions provided for by Art. 11.1.c) AS is present, theoretically WTO Members could still play one last card: to conclude inter se agreements that, although in contrast with the multilateral discipline, remain valid even if they can give rise to international responsibility. A responsibility that other States seem to be rather unwilling to claim (as confirmed by the silent reaction to the 2006 Agreement between the United States and Canada on softwood lumber).

In a broader perspective, the topic examined in this work shows that the regulation of trade relations can vary depending on the pair of WTO Member States 
participating in a legal relationship. This potential fragmentation of the multilateral legal framework governing international trade may be as much the result of agreements restricting exports authorized by the system, as the result of conventional solutions that are neither permitted nor permissible under Art. 41 of the Vienna Convention on the Law of Treaties, yet are still largely tolerated. In this respect there can be more than a doubt on the existence of a qualitative distance from the GATT à la carte, ${ }^{73}$ i.e., that mosaic of special schemes, exemptions and side-agreements that the creation of the WTO was intended to replace.

73 On this topic, see J. Cazala, 'L'O.M.C. à la carte? Les aménagements conventionnels aux obligations des membres permis par le droit conventionnel de l'Organisation mondiale du commerce', 113 Revue générale de droit international public 2009, p. 45 ff., at p. 65. 